\title{
THEORY AND METHOD: BRIDGING THE GAP BETWEEN HISTORY AND ARCHEOLOGY
}

\author{
ALBERT VAN WIJNGAARDEN \\ Novosibirsk State University, Russia \\ Albertvanw@gmail.com \\ LILIAN KARALI \\ National and Kapodistrian University of Athens, Greece \\ likarali@yahoo.com
}

\begin{abstract}
This article aims to bridge the gap between history and archaeology by linking the methodological and theoretical developments of both scientific disciplines. This is done by tracing general societal trends and developments within both disciplines, divided into five periods, from the professionalization of the sciences in the nineteenth century, up to the present day. The result will hopefully offer practitioners of both disciplines an insight into the others' intellectual framework, and thereby foster better understanding and opportunities for future cooperation.
\end{abstract}

KEYWORDS: History, Archaeology, Method, Theory, Philosophy.

\section{Introduction}

Most articulations on the relationship between history and archaeology repeat the same old cliché: although both deal with the past, the former accesses it through archives, while the latter digs up its physical remains from the earth. So described, the difference appears small, almost trivial. But when one then proceeds to the universities and sees how the scientific disciplines have set themselves up, the differences seem suddenly vast, with scientists sticking to their own respective field, not minding either the "diggers" or the "archive dwellers", and referring practically solely to their own disciplinary colleagues in their footnotes.

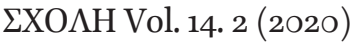

www.nsu.ru/classics/schole
(C) Albert van Wijngaarden, Lilian Karali, 2020 DOI:10.25205/1995-4328-2020-14-2-456-469 
Apart from a few famous exceptions, most notably R. G. Collingwood, one would be hard pressed to name scholars who bridged this divide. The discrepancy appears even stranger when one thinks of all the sub-fields within archaeology and history that seem to have a lot more in common with their peers across the hallway than with their mother discipline. Why should industrial archaeology be so far removed from industrial history, or environmental history from environmental archaeology? Even a field like historical archaeology, despite its name, mostly relies on its mother discipline of archaeology.

This article does not intend to make both disciplines merge or to claim that there are no good reasons why archaeology and history should be separated. The point is rather that there is much to learn from each other, and that scholars can benefit from taking note of the developments and ideas behind their sister disciplines. The goal of this article is to advocate a surpassing of the old, "conflictual stance", wherefrom archaeologists ignore "vague", "interpretation based" history, and historians see archaeology as nothing more than history's 'handmaiden' (Ivor Noël Hume 1964). Instead, it is argued, the two disciplines should come together and profit from a revitalised communication, based on a mutual understanding and shared recognition of points of commonality as well as differences.

This article aims to contribute to other efforts to make a start with fostering such an understanding by tracing and subsequently connecting the historical trajectories of the self-perceived developments by practitioners of the two disciplines. In other words, to show how historians and archaeologists perceived their respective scientific fields, as well as the differences between their fields, and how this has changed over time. Through this entangled history of ideas, a clearer image will appear of who and what influenced both disciplines respective perspective of what comprised a successful analysis of the past, and how developments in the way they saw their own task, reflect developments and the general sociocultural environment of their time.

Although human interest in what happened before goes back to time immemorial, and one might have started this exploration at a much earlier date, the most significant parallel scientific trajectory appears in the nineteenth century, when both history and archaeology professionalised, as this was a time when groups of practitioners got together and started to discuss and systematically develop methods by which they could best probe into the past.

Following this starting point, the development of both disciplines is traced right up to the present. For practical reasons a division of the timeline into periods is proposed: (1) the pre-WWI period, (2) the 1918 - 1945 period, (3) the period from 1945 to the 1970s, (4) the period from the 70's until the early 21st century, and (5) the contemporary thinking about both disciplines. Obviously, this artifi- 
cial division, like every periodization, makes the past morph into shapes that are figures of interpretation, and many flaws and points of discussion will inevitably come up. The start- and end points of the periods are therefore not necessarily clear points at which a significant shift can be perceived, but rather artificial in retrospect perceived tipping points after which a tendency gained proliferation across the field. Even though the periodization therefore might suggest the existence of clear boundaries, this is in not the case, as many developments and ideas originated earlier. Equally, certain trends were not shared amongst all practitioners in the field. However, these trends can be considered symbolic for the spirit of the time and the most successful approaches during that period.

Lastly, due to the length of this article and in order to not repeat what is already written the focus has been laid on drawing connections and revealing an entangled history, not to give a new or exhaustive account of the topic. For these reasons, there are but a few references throughout the article, and only a selected bibliography at the end. However limited, these key-works would be beneficial to both disciplines, and the knowledge of each other's theoretical background will be crucial for further debate and mutual recognition between historians and archaeologists.

\section{Pre-WWI}

Although people have probably always speculated about what came before, and there have equally long been attempts to find out what had happened to their ancestors, developments in nineteenth century Europe can be marked as a significant change in humanity's dealing with the past. It was in that century that the study of the past morphed from being a hobby for amateurs or a source of legitimacy for rulers, into a more systematic enquiry using specific methods whose outcomes were debated by professional practitioners, who served as judges regarding the soundness of the findings. This was a time when the study of the past became professionalised and started to more closely resemble the academic disciplines of history and archaeology that we know today.

Key to understanding the drives of archaeologists and historians in this initial phase of scientification was their shared societal role. As nations were being formed, and identities carved out, the student of the past held a key position within society: through the lines that they traced back through time, the present groups could be shaped. Historians therefore mostly wrote about the "great men" of history and national developments through which their nation had emerged, while archaeologists concerned themselves mainly with ancient lineages that were thereafter to be tied to the contemporary reality. Both historians and ar- 
chaeologists therefore took part in the construction of national and cultural pasts that could be used to serve political goals.

Alongside this shared broader function of their work, archaeologists and historians also often held similar philosophical assumptions about the nature of temporal development. Key to both disciplines' conceptions of the past was the idea of progress underlying the passage of time, broadly perceived in scientific and technological advancement, and in the second half of the nineteenth century given extra impetuous by the popularity of Darwin's theory of evolution.

Amongst historians, this belief appeared for instance in the widespread universalist scope of their histories, implying that all stories of the past could and would ultimately come together in one story of development. Or, in the words of the end of the nineteenth century's most influential philosopher Herbert Spencer: 'Progress, therefore, is not an accident, but a necessity... [S] urely man must become perfect' (Spencer 1851, 65). These universalist histories were very much founded on Eurocentric, and often also racist premises, implying that the world would in time be civilized in a European model.

This idea showed even more clearly in archaeologists' unilinear perception of cultural and social development. Adherents of this conception of development believed that Western culture was the center of social evolution whose development could be seen as the progression along a single line, starting from various stages of primitive life to most civilized stages. According to these theorists, all cultures had developed in a similar fashion from "savage" hunters and gathers, to "barbaric" farming communities, ending in the end goal of "civilized" modern western culture. Although alternative multilinear theories had already been proposed, most famously by Franz Boaz, these only replaced unilinear theory later in the twentieth century.

But although historians and archaeologists broadly shared their societal function and philosophical perception of historical development, there was also a major methodological gap separating them. The historical discipline had professionalised much earlier, and scientific historians had firmly solidified their position as a science within the academy. In the wake of Leopold von Ranke, who set the standards for a discipline that aspired to find out wie es gewesen by delving into archives and using strict methods specific to the discipline, history had reached a status it would never attain again. Historians, in this golden era that would later be associated with the term historicism (historismus in German), were strengthened by a belief that the knowledge they produced was a special kind of 
knowledge that was, according to some, preferable over that what the natural sciences produced, as it aimed at verstehen, rather than erklären. ${ }^{1}$

Archaeology's ascent into academia started much later. But although wealthy amateurs remained important, gradually, treasure hunts were replaced by systematic excavations making use of typologies based on the detailed parallel examination of geographic areas and sites. This first period of scientific archaeology has often been labelled cultural-history archaeology, because the researchers tried to catalogue, describe, and create timelines, based on artefacts, without concerning themselves with complicated structural interpretations between cultures and digs. Instead of a hermeneutical attempt at understanding the past through empathy, like historians did, archaeologists approached the past much more empirically, greatly borrowing and learning from natural and life sciences as geology and biology. Archaeologists therefore were leaning much more towards positivism and empiricism than historians, and therefore sometimes perceived their work as a sort of anti-history (Veit 2011).

This is not to say that both camps were explicitly and fundamentally opposed, or that there was ever clarity over what and how both sciences were operating, and how they should do so in the future. There were many dissenting voices that criticized the ways in which historians and archaeologists dealt with the past. Amongst historians, Friedrich Nietzsche's complex critique on the usefulness (although it deals rather with uselessness) of history has perhaps become most famous. But many other critiques were levelled, and although Jacob Burckhardt's pioneering work in cultural history was only later fully recognised, and Karl Lamprecht lost the Methodenstreit to supporters of traditional ways of writing history and political history, by the advent of WWI the historicist movement had already largely run out of steam. Archaeology too was constantly developing, as new impetuous was given by technological innovations, and influence from anthropological theories was changing the way archaeologists regarded culture and its development. Tellingly, Collingwood observed the start of a 'Baconian revolution' in archaeology in 1909 (Collingwood 1939, 115).

However, despite the new innovations and techniques, and the many challenges from within the disciplines, the main impact on both fields came in the wake of the First World War, when the underlying assumptions about historical development were fundamentally challenged.

\footnotetext{
${ }^{1}$ Despite disagreement about the meaning of historicism, here the term refers to the program that departed from the assumption that everything has a historicity and historical development, and can therefore be better understood by studying its history, not by reference to larger principles or theories.
} 


$$
2.1918-1945
$$

The Great War sowed doubt amongst those who had previously believed in progress. The innovations that had seemed to advance society had also helped make the carnage that ensued possible. Furthermore, if people had willingly started this conflict and thrown themselves in the war, what then was there to be made of the old ideal of rationality? This was at all the more questioned due to the immense influence of Sigmund Freud's theories about the workings of the unconscious. Where did this leave European civilization that had previously been perceived as the centre of human development? The idea of progress of course never fully disappeared, and famously came back in E. H. Carr's What Is History? (1961), probably reached a climax with the collapse of the Soviet Union and Francis Fukuyama's declaration of an 'end of history' (1989). But it is undeniable that many did question the concept in itself, and formed varied new ideas in its stead.

Some thinkers therefore altered their linear progressive theories and replaced them by a circular development of rise and fall of cultures. Most famous and influential was of course the German Oswald Spengler, who, with his 1922 Decline of the West became the mouthpiece for cultural pessimists. This perspective was often reused, for example in historian Arnold Toynbee's 1939 A Study of History. Many of these cultural narratives expounded a dread for the disappearance of past glory and an uncertain future that was going to be dominated by a new force.

Others responded oppositely, in a more progressive fashion, writing them against the War and the nationalisms that historical narratives had helped to create. Instead of looking melancholically and pessimistically backward to lost glory, they wanted to move away from the hierarchical distinction between nations and people in order to prevent future conflict. Although not a professional historian, H.G. Wells' bestselling The Outline of History is a prime example of this antipessimistic attitude. In the introduction of this pioneering work in the field of global history he writes: 'there can be no common peace and prosperity without common historical ideas.' (Wells 1920, vi). Continuing to write that 'A sense of history as the common adventure of all mankind is as necessary for peace within as it is for peace between the nations.' In archaeology, Gordon Childe took a similar position, claiming in his Man Makes Himself to attempt to safeguard the idea of progress against 'sentimentalists and mystics' (Childe 1936, 16). Instead of the simplistic unilateral cultural developmental theories, he argued that a lot of the culture in Europe was not developed here, but imported from the Middle East.

However, despite the popularity of cyclical theories, and attempts to do away with the mythical histories that sought to glorify the nation, many historians and archaeologists kept writing the same old European and Western-centred narratives as they had been doing before the War. Moreover, as many colonies re- 
mained under white imperial sway, a Western centric universal story was still very much possible to tell, and could be reinforced with racial elements to form a narrative of the superiority of white Western civilization.

That change was on the horizon showed also in shifting interest amongst some scholars of the past. Marc Bloch and Lucien Febvre, the famous founders of the French Annales School, are the most obvious examples of historians who broke radically with traditions by combining an interest in different topics, with new methods from psychology, economics, and geography. But they were not the only ones who innovated. In America progressive historians paved the way for later social history, something also the first Marxist historians aspired to do. Also in other fields, like cultural history, masterpieces were being written, a prime example being Johan Huizinga's Dawn of the Middle Ages.

Within archaeology, now firmly within the walls of academia, new schools and topics of interest also took hold. O. G. S Crawford proposed a more concrete geographic approach to the study of the past, and introduced a geophysical methodology. J. Steward introduced "cultural ecology", and looked for cultural change based on the interaction among human societies and the immediate environment using archaeological and historical data. Although this was also true for history, for archaeology especially, these new ways of thinking were made possible by technological and methodological advances in the field.

In summary, the period between the two World Wars can in some ways be seen as a continuation of previous intellectual tendencies: many historians and archaeologists kept working on similar topics, with similar underlying thoughts, and the stories they told were still often in line with political goals of the period as western-centric and national narratives dominated. But, this was not done as self-confidently as before. As the most famous American historian of the period, Charles Beard, observed: 'historians were not so sure of themselves after 1918' (cited in Novick 1988, 186). And, even though many of the new techniques and approaches were only to become truly influential during the second half of the twentieth century, this was also a time of great innovations that were to profoundly influence the way archaeologists and historians perceived their respective disciplines.

\section{1945 to the 197 os}

The First World War had already shaken the faith in the old ways of writing and doing history and archaeology, but after the Second World War there certainly seemed to be a dire need for innovation. Furthermore, with evermore colonies gaining their independence, the old tendency to write progressive universal histories, hinging on an underlying belief in Western superiority, was no longer credible. 
Partially, this resulted in the writing of histories from different perspectives, giving voices to those who had not had one before: minorities, women, former colonised nations, or the working classes. But in many ways, innovators responded with a turn to scientific positivism, and an emphasis on the role of structures and quantitative research methods. Like was the case in the destroyed post-war societies, reconstruction was going to happen with the help of science and rationality. This had already been part of the methodology of both disciplines to some degree, especially amongst archaeologists, but it now became a much more commonplace practise.

Theories of structuralism, following Claude Levi-Strauss' popularity and impact amongst the social sciences, were a first important influence. These ideas were especially influential amongst archaeologists, who were much more strongly connected to anthropology and structural ideas, especially in the United States were archaeology was, other than in Europe, part of the anthropology departments.

Most exemplary of the post-War spirit however is the influence of the work of Carl Gustav Hempel. Hempel argued in The Function of General Laws in History that 'Historical explanation, too, aims to show that the event in question was not "a matter of chance," but was to be expected in view of certain antecedent or simultaneous conditions.' Rather than relying on hermeneutical methods, Hempel argued that historians should apply 'rational scientific anticipation which rests on the assumption of general laws.' (Hempel 1942).

Methodologically, archaeology received an enormous stimulus from one of the most important inventions in the field: the introduction of (C14) radioactive carbon dating by W. Libby in 1949. But the theoretical development left an equally great impression upon the archaeological discipline. The empiricist, positivistic spirit of the time led some archaeologists to a radical rethinking of what their discipline entailed. After earlier initiatives in America, Lewis Binford and a team of young archaeologists proposed a new approach to the problem of interpretation of the social and economic development of past, called "New Archaeology" (Binford 1968). The processualists, as the adherents of this movement like Colin Renfrew and David Clarke later became known, wanted archaeological reasoning to be based strictly on a logically sound skeleton of arguments. Instead of merely describing artefacts, they focussed on typology and the classification of objects by emphasising the importance of the analysis of larger systems through interpretation of its parts. Culture thereby became a system structured from sub-systems that could, for example, be analysed through the study of diet, technology, society, ideology, trade, demography, or the environment. This meant that the "New Archaeologists", even more frequently than before, made use of methods from the positive sciences, such as the organization of space based on geography. 
Although historians were less strongly impacted by the empirical and positivist spirit of the time, many of them, often inspired by Marxist thought, turned to social and economic history, replacing the old political narratives with new histories, relying heavily on quantified sources. E. P. Thompson's 1963 Making of the English Working Class is a famous example of this. But this period's spirit shows most clearly at the popularity of the Frenchman Fernand Braudel, who, as the new leader of the Annales, represented a new kind of history. In his 1949 classic, The Mediterranean, he steps away from the short term politics and evenements, and, applying findings and methods from various social and natural sciences, turns to the larger scales, that, according to him, determine history to a much more important degree than the short term events to which historians generally devoted much of their time.

With this positivist empiricist tendency reappearing, and archaeology radically reinventing itself, the age-old debate around the difference between the humanities and the hard sciences resurfaced once more. Processual archaeologists aligned themselves clearly alongside the sciences. This shows for example from Clarke's remarks about the crisis in archaeology stemming from attempts by nonprocessualists' to write 'imitation history books' (Clarke 1968, 11). On the other side, scholars like Moses Finley called the pure scientific endeavour "bloodless", and stressed the commonalities between history and archaeology (Finley 1971). Ivor Noël Hume went even further and infamously described the archaeological discipline as 'the handmaiden to history' (Hume 1964).

Even though the period of post-War positivism came to a close when postmodernism and the other post-isms made their entrance around the end of the 6 os, for both history and archaeology the age-old questions of objectivity of the historical studies had always been looming in the background. The status of the objectivity of historical enquiry in historiography had for instance flared up in the debate between E. H. Carr who questioned the existence of historical facts in What Is History? (Carr 1961), and Geoffrey Elton, who defended objective history and historical facts in The Practice of History (Elton 1967). But these debates were by long last not as radical as those which Hayden White and other narrative philosophers of history would initiate a few years later. In Archaeology it took a bit longer, but Ian Hodder and other post-processualists eventually caused similar shockwaves throughout to ripple through the archaeological discipline.

\section{4. $70^{\prime}$ 's until the early $21 s t$ century}

Despite disagreement over what is meant by the term "postmodern(ism)" and how relativist the critique of the so-called postmodernists really was, it is clear that there was a broad change in thought in academia (and society at large), 
roughly from the 7os onwards (Harvey 1989). Old narratives and conceptions of truth, values, and progresses were challenged, and previously muffled voices were allowed to speak. What was perhaps most impactful was that even the dream of objectivity of the natural sciences was shattered at the hands of the work of the likes of Thomas Kuhn, Michel Foucault, and Paul Feyerabend.

This movement was also clearly visible in thinking about history and archaeology. In response against the positivistic promise that had gained prominence during the 6os, in both fields, several things changed: there was a challenge to the claim that it was possible to come to objectively true knowledge, the impact of the researcher and his/her bias was emphasised, the importance of language and narratives reaffirmed, and a general incredibility towards meta-narratives was installed amongst practitioners.

In historiography, the postmodern turn has often come to be known under the more methodologically related names of narrative or linguistic turn, and alternatively as the cultural turn, which refers to the new sub-field many historians then turned to. There were however many different aspects and sub-fields that emerged during that period, from an interest in the role of memory in historical research to micro-, oral-, and postcolonial history. Apart from the appearance of these new fields and voices within the discipline, the postmodern effect on the historical discipline mainly came through the work of theoreticians like Hayden White, Paul Ricoeur, and Frank Ankersmit, who addressed issues like the subjectivity and bias of the historian, raised questions as to how a historical narrative functions, and asked what that meant for the position of history amongst the sciences. But most importantly, they took aim at history's claim to be able to produce (objective) knowledge about the past. This was according to them to a large degree an illusion. Instead, they argued that in a sense, every narrative presented a selected picture of the past, and that therefore there was no real right or wrong distinction between competing narratives, but at most a better and a worse option.

Archaeologists like M. Shanks, C. Tilley, D. Miller, P. Ucko and most notably I. Hodder, levelled a similar attack to the positivistic ideals within their discipline, and argued for a turn to post-processualism. Their critique was directed to the claim that, if the scientific method was applied, the archaeologist could reach an objectively true conclusion. Post-processualists thereby responded to what Alison Wylie later called the Proceccual archeologists' "paralyzing demand for certainty" (Wylie 1985). Instead, Hodder and the other processualists argued that archaeologists could never be completely objective in their scientific approach because they were all in some form or other prejudiced by their personal experience and cultural context. 
An important result of these movements is that, broadly speaking, historians and archaeologists looked for responses to similar issues, and thereby the stark distinction between the more quantative methods of archaeology, based on the natural sciences, and the more hermeneutical traditions of history disappeared somewhat, this meant that - at least theoretically - there appeared room for a theoretical coming together of history and archaeology.

There is however one striking discrepancy in the postmodern turns of history and archaeology, and that is timing. History had its turn somewhere in the 7os, with White writing his article The Burden of History in the late 6os, and his Metahistory published in 1973. Postmodern ideas were therefore already widespread in historical theory in the eighties. But archaeology only started with its turn around that time, with Hodder's seminal texts appearing only well into the eighties. That is not to say that archaeology became self-critical later. Famously, Clarke, as a proponent of processualism, had already declared the loss of archaeology's innocence in 1972 with processualism's innovations. What than might be the cause of this time gap between the two turns? An explanation might be found in the different attitudes both disciplines have towards the other sciences and their objects of study. Whereas historians had long since asked questions regarding scientific objectivity, the archaeological discipline, with its firmer roots in the natural and social sciences and reliance on "solid" quantifiable data with which they physically interacted, might have staved off the need to ask similar questions.

In the end however, both archaeological and historical theory were completely saturated with postmodern ideas. Opponents of postmodern turns have often linked it to a perceived crippling nihilism, and have highlighted that from there logically follows that "anything goes", although it is clear that most so-called postmodern theoreticians stayed far away from such extreme standpoints. For archaeologists, the post-processual movement can be said to have caused a theoretical boom within the discipline, although perhaps to a degree that it overstated its relevance and stifled actual work. Many historians in the field did not take too much heed of the theoretical wars that ravaged, and many histories continued to be written in a similar fashion, albeit with the knowledge that certainty within historical science was now being questioned. What was the clearest result of the movements was that new ideas and voices now took their place within the disciplines, allowing for both history and archaeology to develop into much broader scientific fields, that asked and answered questions that concerned more than just the old privileged Western-centred patriarchal world. 


\section{Contemporary developments}

Even though periodization is only possible in retrospect, there are some essential contemporary developments in thought about history and archaeology and the philosophy of the sciences in general that are relevant for the present discussion. The main mental shift has to do with a wider letting go of the theoretical angst of the perceived relativity that came with the influence of postmodern theories. The spectre of relativity partially disappeared because it was ignored, with many people simply passing over theory, and getting on with praxis. But one could also point to more concrete reasons having to do with an engagement with postmodernity. For historians, the outcome of the Irving v Lipstad trial for example showed that there were objective "historical facts" before the law, as historians had to prove the Holocaust had actually happened (Lipstadt 2005).

And theoretically also, for both archaeology and history, in the last decade or so, neo-materialist tendencies and an interest in "praxis" have furthermore tried to overcome the focus on language and the constructed. Instead, a midway between constructivism and realism might be offering a way out of either a relativist world in which all meaning is constructed, and a rock-solid world in which culture, thought, and interpretation have no role to play.

Concretely, as material and textual sources have become essential to both history and archaeology, this has in some cases resulted in a coming together of the disciplines. This shows perhaps most clearly in the field of historical environmental studies, where environmental archaeologists, and environmental historians are largely dependent on the same materials and are engaged in writing similar histories. Exemplary of this process is how Dipesh Chakrabarty in his influential essay The Climate of History (2008) claimed the Collingwoodian notion that all history is the history of ideas (and that nature has no part to play in that) is refuted because mankind now has become a geological agent, and therefore the perceived gap between natural events and human actions driven by motives collapses (Chakrabarty 2009).

Rapprochement between history and archaeology is also to be expected with advances and technical innovations in the digital humanities. Think for example about the easily accessible and analysable material, but mainly also of large collaboratory projects wherein historians and archaeologists work alongside to reconstruct and analyse the past.

However, despite these encouraging instances of cooperation, there are also plenty of examples to be given that illustrate the continuing existence of the gap between history and archaeology, and isolation between the sciences still remains largely the norm in academia. 


\section{Conclusion}

Archaeology and history do not have an end. The question of how ecofacts, artefacts, texts, and typographies related to cultural and environmental issues should be processed, categorized, and narrated in the most effective and systematic way, remains an open one. Despite growing similarity and potential to cooperate, there is still hardly any interaction between history and archaeology. Like stated before, this article does not advocate a joining of the sciences, but rather reveals that the old cliché of digging archaeologists against archive-dwelling historians is neither adequate nor productive. It is intended as a starting point from where practitioners from both disciplines can gain access into each other's intellectual background. From this initial cooperation it might be possible to foster further development and make future cooperation easier. Although it has become clear from the above that there have been plenty of times during which the disjunction between history and archaeology grew, the recent conjoining tendencies must stem historians and archaeologists hopeful for the times to come.

\section{REFERENCES}

Binford, L. R. (1968) New Perspectives in Archaeology. Chicago: Aldine.

Carr, E. H. (1961) What Is History? London: Macmillan.

Chakrabarty, D. (2009) "The Climate of History: Four Theses," Critical Inquiry 35.2, 197-222.

Childe, G. (1936) Man Makes Himself. London: Watts \& Co.

Clarke, D. L. (1968) Analytical Archaeology. London: Methuen.

Collingwood, R. G. (1939) An Autobiography. Oxford University Press.

Elton, G. (1967) The Practice of History. London: Methuen.

Finley, M. I. (1971) “Archaeology and History," Daedalus 100.1, 168-186.

Fukuyama, F. (1989) “The End of History?” The National Interest 16, 3-18.

Harvey, D. (1989) The Condition of Postmodernity: An Enquiry into the Origins of Cultural Change. Oxford: Blackwell.

Hempel, C. G. (1942) "The Function of General Laws in History," The Journal of Philosophy 39.2, $35-48$.

Hume, N. I. (1964) "Archaeology: Handmaiden to History," The North Carolina Historical Review 41.2, 214-25.

Lipstadt, D. E. (2005) History on trial: my day in court with David Irving. New York: Harper Perennial.

Spencer, H. (1851) Social Statics. London: John Chapman (https://oll.libertyfund.org/titles/spencer-social-statics-1851).

Veit, U. (2011) "Über das "Geschichtliche" in der Archäologie - und über das "Archäologische" in der Geschichtswissenschaft," in Burmeister, S., Müller-Scheeßel, N., eds. Fluchtpunkt Geschichte: Archäologie und Geschichtswissenschaft im Dialog. Münster: Waxmann, 297-310.

Wells, H. G. (1920) The Outline of History. New York: George Newnes. 
Wylie, A. (1985) "The Reaction against Analogy," Advances in Archaeological Method and Theory 8, 63-111.

\section{SELECTED BIBLIOGRAPHY}

Beiser F., C. (2011) The German Historicist Tradition. Oxford University Press.

Binford, L. R. (1968) New Perspectives in Archaeology. Chicago: Aldine.

Bloch, M. (1953) The Historian's Craft [1940]. New York: Knopf.

Burke, P. (2015) The French Historical Revolution: The Annales School, 1929-2014. Stanford University Press.

Carr, E. H. (1961) What Is History? London and Cambridge: Macmillan.

Chakrabarty, D. (2009) "The Climate of History: Four Theses," Critical Inquiry 35.2, 197-222.

Clarke, D. (1973) "Archaeology: the loss of innocence," Antiquity 47, 6-18.

Collingwood, R. G. (1946) The Idea of History. Oxford: Clarendon Press.

Doran, R., ed. (2013) Philosophy of History After Hayden White. London: Bloomsbury.

Earle, T. K. \& Preucel, R. W. (1987) "Processual Archaeology and the Radical Critique," Current Anthropology 28.4, 501-538.

Evans, R. J. (1997) In Defence of History. London: Granta Books.

Hempel, C. G. (1942) "The Function of General Laws in History," The Journal of Philosophy 39.2, $35-48$.

Harris, O. J. T. \& Cipolla, C.N. (2017) Archaeological Theory at the Millennium: Introducing Current Perspectives. London: Routledge.

Hodder, I. (1999) The Archaeological Process: An Introduction. Oxford: Blackwell.

Hodder, I. \& Hutson, S. $\left(2003^{3}\right)$ Reading the Past: Current Approaches to Interpretation in Archaeology. Cambridge University Press.

Iggers, G. (2005) Historiography in the 2oth Century: From Scientific Objectivity to the Postmodern Challenge. Middletown: Wesleyan University Press.

Jenkins, K. (1991) Rethinking History. London: Routledge.

Johnson, M. (2010²) Archaeological Theory: An Introduction. Oxford: Blackwell.

Karali, L., Afonasina, A., \& Afonasin, E. (2019) "An Outline of the History of Archaeology," $\Sigma X O \Lambda H($ Schole $)$ 13.2, 823-840.

Kramer, L, \& Maza S., eds. (2006) A Companion to Western Historical Thought. Oxford: Blackwell.

Nora, P. (1989) "Between memory and history. Les lieux de mémoire'," Representations 26.1, 724.

Popkin, J. D. (2015) From Herodotus to H-Net: The Story of Historiography. Oxford University Press.

Renfrew, C. \& Bahn, P. (20167) Archaeology: Theories, Methods and Practice. London: Thames and Hudson.

Tosh, J. $\left(2010^{5}\right)$ The Pursuit of History. Harlow: Pearson.

Trigger, B. G. $\left(2007^{2}\right)$ A History of Archaeological Thought. Cambridge University Press.

Tucker, A., ed. (2009) A Companion to the Philosophy of History and Historiography. Oxford: Blackwell.

White, H. E. V. (1966) “The Burden of History," History and Theory 5.2, 111-134. 